\title{
Study on effectiveness of flood control based on risk level: case study of Kampung Melayu Village and Bukit Duri Village
}

\author{
Mohammad Farid ${ }^{1, *}$, Harni Harumi Pusparani ${ }^{2,3}$, Muhammad Syahril Badri Kusuma ${ }^{1}$, and Suardi Natasaputra ${ }^{2}$ \\ ${ }^{1}$ Water Resources Engineering Research Group, Faculty of Civil and Environmental, Institut Teknologi Bandung, 40132, Bandung \\ Indonesia \\ ${ }^{2}$ Professional Master Program in Water Management, Institut Teknologi Bandung, 40132 Bandung, Indonesia \\ ${ }^{3}$ Ministry of Public Works and Housing, 40393 Bandung, Indonesia
}

\begin{abstract}
Jakarta, the capital city of Indonesia, experiences flood which causes activities disruption and losses almost every year. Many studies have been done to mitigate the impact of flooding. Most of them focus on reducing the inundated area as an indicator of the effectiveness of flood control. This study aims to evaluate the effectiveness of several flood control alternatives based on risk level reduction. The case study is located in Kampung Melayu Village and Bukit Duri Village which are densely populated with several economic area and almost every year experiencing severe flooding in Jakarta. Risk level analysis was carried out by the method based on guidelines issued by the Head of National Disaster Management Agency (BNPB) No. 2/2012 with few modifications. The analysis is conducted on five alternatives of flood control which are diversion channel to East Flood Canal (KBT), diversion channel to the West Flood Canal (KBB) in Pasar Minggu, river improvement, capacity enhancement on all components, and capacity enhancement focusing on one component. From the results, it is showed that enhancing capacity which focus on preparedness component by two levels are the best in terms of investment value to risk level reduction.
\end{abstract}

\section{Introduction}

Flood is identical with disaster due to its loss impact especially in urban areas. Special Capital Region (DKI) Jakarta is one of the most flood-prone area in Indonesia. In 2002, Jakarta experienced the first severe flood in the $21^{\text {st }}$ century which caused widespread damage and affected more than $75 \%$ of the total population of the city [1]. Furthermore, based on the report from National Development Planning Agency (Bappenas) in 2007 [2], damages and losses caused by floods that occurred in 2007 were estimated to reach 5.16 trillion rupiah which almost $70 \%$ from this number was in economic sector. While on January 15, 2013, major floods in Jakarta and West Java had caused at least 40 people died, 45 thousand refugees, and considerable economic losses [3].

One alternative way in determining priorities and action of flood management is conducting risk analysis [4]. There are differences of risk determinant factors level of each area, whether it is the threats, vulnerabilities, or capacities. By developing the risk mapping of an area the various demands of many users including policy makers, can be fulfilled. Furthermore, variety of purposes such as for awareness building and for communication about the local hazard situation, are also served by the maps [5].

Recently, studies of flood management effectiveness based on risk level is not as much as studies that based on inundation (flood volume), whereas the inundation reduction is not necessarily proportional to the reduction of risk and loss in a region. The aim of this study is to analyse the effectiveness of several flood control efforts based on risk reduction by taking the case study in Kampung Melayu Village and Bukit Duri Village, Jakarta, which has predominance spatial function as settlements area with several points of economic and service.

\section{Methodology}

Flood events used as input in this study was obtained from previous study [6]. According to Jakarta river plan, design flood discharge is for return period of 100 years which is equal to $690 \mathrm{~m}^{3} / \mathrm{s}$.

Risk analysis was carried out according to General Guidelines for Disaster Risk Assessment issued by National Agency for Disaster Management (BNPB) [7] with some modifications considering the location of study. They are the accuracy level of analysis which is village (RW) based, flood classification, and weighting parameter of capacity index.

In this study, except for inundation map, the data sets are collected from institutions and field survey conducted on 9 to 22 November 2015. Some interviews with local people, local government, and the provincial government, represented by the secretary of the village chief and staff BPBDs DKI, are also conducted. The data sets are mainly used as an input to the analysis of

Corresponding author: mfarid_si99@yahoo.com 
population exposure index, losses index, and capacity index. Those data sets are demographic data, buildings and public facilities data, economic condition, capacity condition, and infrastructure plans for flood management in the study area [8-10].

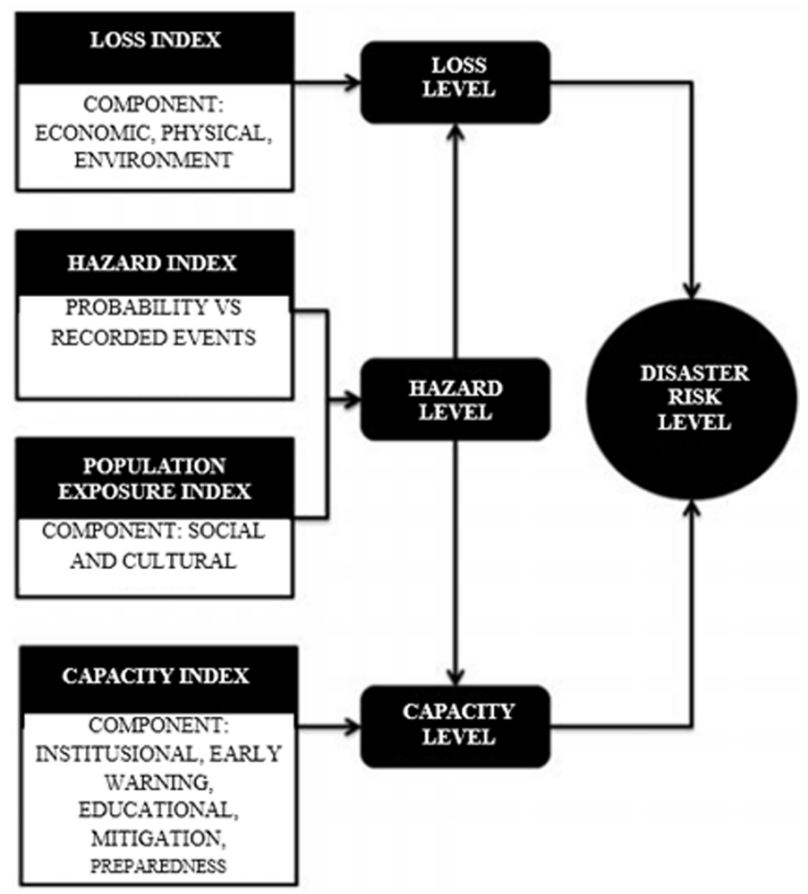

Fig. 1. Methodology of disaster risk assessment

Furthermore, the effectiveness of flood control alternatives were analysed by comparing the investment to risk reduction with also considering area location from the river. Investment which is taken into account is the cost for implementation phase without the cost for planning and maintenance phase. Investment for structural approaches includes the cost for construction and land acquisition, while the investment which are taken into account for non-structural approaches includes the procurement of goods and services, training, and system improvement/development.

\section{Analysis}

\subsection{Hazard analysis}

Hazard parameter indicated by hazard index is determined based on depth and area of inundation. Flood classification used in this study is following classification suggested by Sarminingsih in 2014 [11] which uses a combination of depth and speed of the flow, based on velocity data from BBWS Ciliwung Cisadane as in Table 1.

From the analysis of the hazard index that can be seen in Figure 2 that there are 13 RWs that have hazard index on 100 years return period flooding scenario, while there is no hazard index in RW 2, 3, 4, 5, 6, 7 and 8 Bukit Duri with the same scenario. The colour green, yellow, and red show the low, moderate, and high hazard index respectively.
Table 1. Flood hazard classification

\begin{tabular}{cccc}
\hline \multirow{2}{*}{ Indicator } & \multicolumn{3}{c}{ Flood hazard classification } \\
\cline { 2 - 4 } & Low & Moderate & High \\
\hline Depth & $\mathrm{D}<0,8 \mathrm{~m}$ & $0,8 \mathrm{~m}<\mathrm{D}<1,2 \mathrm{~m}$ & $\mathrm{D}>1,2 \mathrm{~m}$ \\
\hline
\end{tabular}

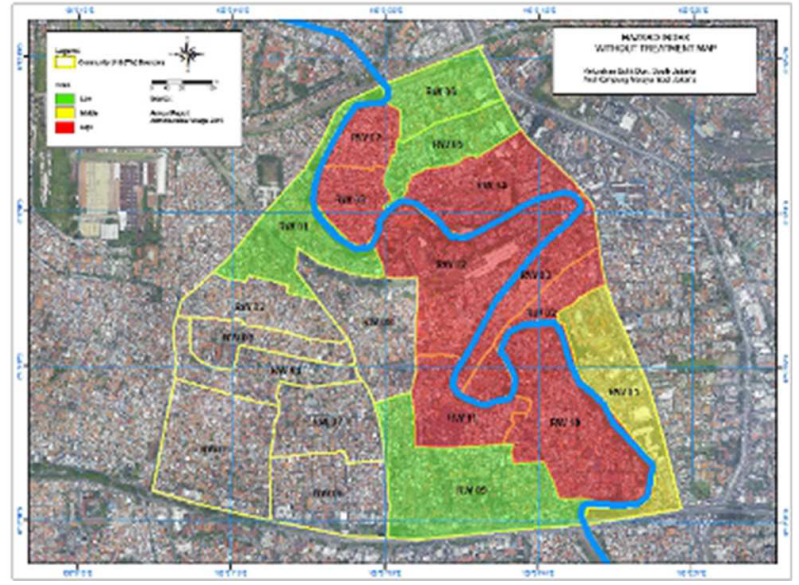

Fig. 2. Hazard index without any action in Kampung Melayu Village and Bukit Duri Village

\subsection{Vulnerability analysis}

Vulnerability parameter described in two indices that are exposed population index determined by social condition and losses index determined by physical condition and economic condition.

Social vulnerability variables that are considered in the analysis are population density, gender ratio, number of children and elderly citizens, and number of disabled/ill citizens. Physical vulnerability that counts is the density of houses, either permanent or nonpermanent, buildings, public and critical facilities consist of religious facilities, educational facilities, medical facilities, electrical facilities, telecommunication facilities, and government/public service offices. Economic vulnerability variables that are taken into account in the analysis is trade sector (i.e. traditional market, mini market, and shop) and industrial sector.

In this analysis, classification of indices and weight factor for each vulnerability components are determined according to the guidelines issued by BNPB in 2012 [7]. While the reference for value per unit variables used in physical and economic vulnerability analysis are obtained from Damage and Loss Assessment, and Recovery Needs due to Jakarta Flood Occurred in January 2013 Report compiled by the Regional Disaster Management Agency (BPBD) Jakarta in 2013 [12]. For some values that are not listed in the report, they were determined from field survey.

Figure 3 and 4 show the analysis of exposed population and loss index. The colour green, yellow, and red show the low, moderate, and high of the index respectively. It can be seen that the exposed population index and losses index in most of the study area are in the moderate and high class. It confirmed the fact that the study area is a dense residential areas with a number 
of trade and industries points, both small and medium scale.

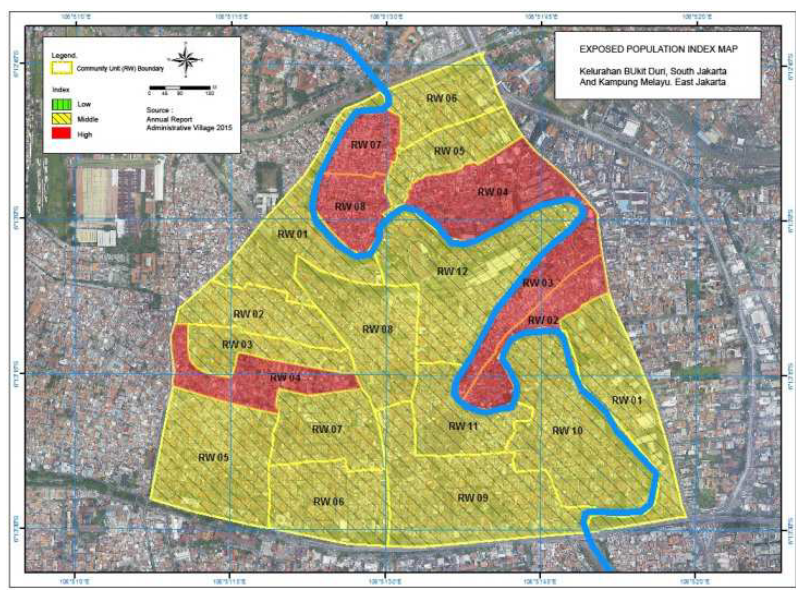

Fig. 3. Existing exposed population index in Kampung Melayu and Bukit Duri

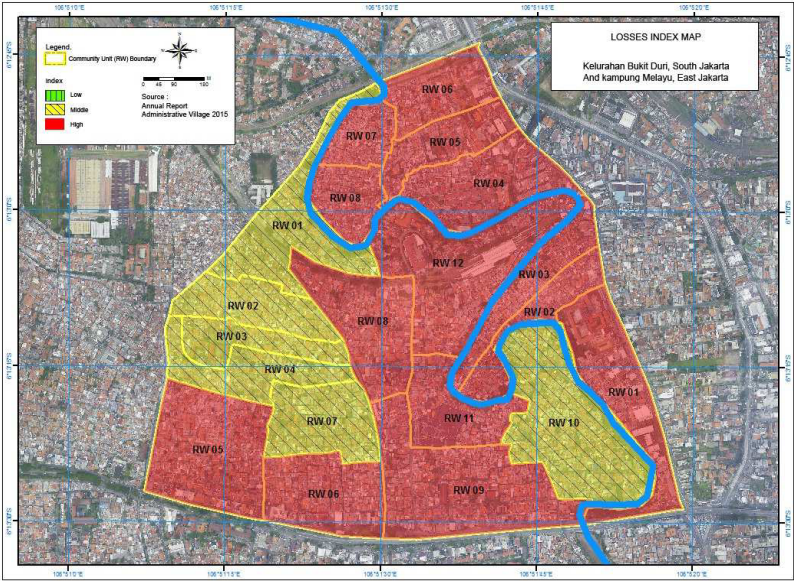

Fig. 4. Exsisting losses index in Kampung Melayu and Bukit Duri

\subsection{Capacity analysis}

Capacity index is determined by five components consisting of 22 achievement indicators based on Hyogo Framework for Action (HFA), according to the BNPB Head Regulation number 2 in 2012 [7]. Those five components are legal and institutional, early warning system and disaster risk assessments, disaster education, efforts for reducing basic risk factors, and preparedness development on all levels.

There are five levels of capacity depends on achievements and supporting system in order to reducing losses due to flooding. Table 2 shows the region capacity indicator levels.

A number of variables used in the assessment of the region capacity, e.g. availability and implementation of legal and master plan, flood control infrastructure condition, disaster response officer, early warning system, training and simulation, land use and spatial plan, access road condition, drainage, SOP for disaster response and also inventory of casualties and damage.

From the analysis of the capacity index that can be seen in Figure 5, the capacity index of Kampung Melayu is higher than Bukit Duri. The colour green, yellow, and red show the low, moderate, and high of the index respectively. Capacity index in the study area is mainly reinforced by early warning system, mitigation system at local level and citizens who are familiar with flood.

Table 2. Region capacity indicator levels

\begin{tabular}{|c|c|c|c|c|}
\hline \multirow{2}{*}{ Level } & \multicolumn{3}{|c|}{ Indicator } & \multirow{2}{*}{$\begin{array}{c}\text { Capacity } \\
\text { index }\end{array}$} \\
\cline { 2 - 4 } & Achievement & $\begin{array}{c}\text { Legal } \\
\text { policy }\end{array}$ & Commitment & \multirow{2}{*}{ Low } \\
\hline 1 & Small & No & No & \\
\hline 2 & Sporadic & No & No & Moderate \\
\hline 3 & Enough & Yes & Low & \multirow{2}{*}{ High } \\
\hline 4 & Good & Yes & Enough & \\
\hline 5 & Comprehensive & Yes & Good & \\
\hline
\end{tabular}

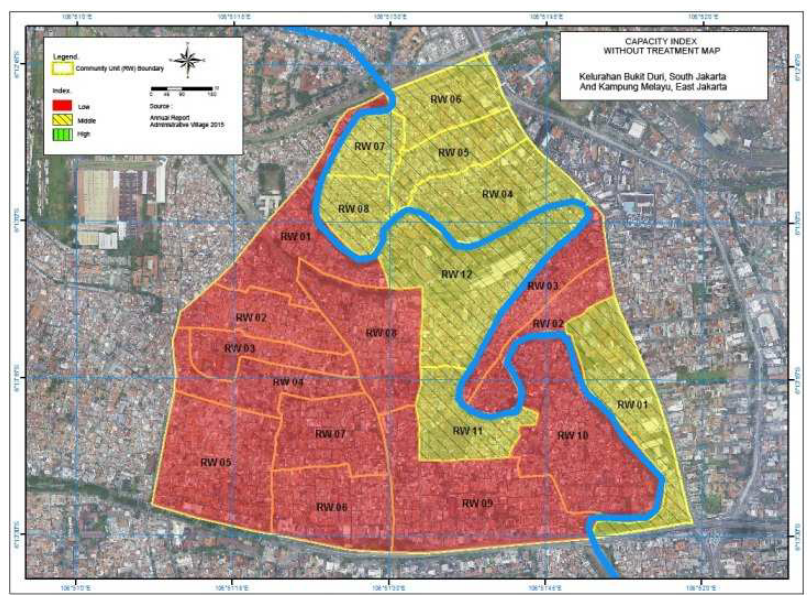

Fig. 5. Existing region capacity index in Kampung Melayu and Bukit Duri

\subsection{Risk level analysis}

Next process is analysing hazard level by taking hazard index and exposed population index into account. Then it will be input in losses index and capacity index analysis which product of these two indices is called risk level.

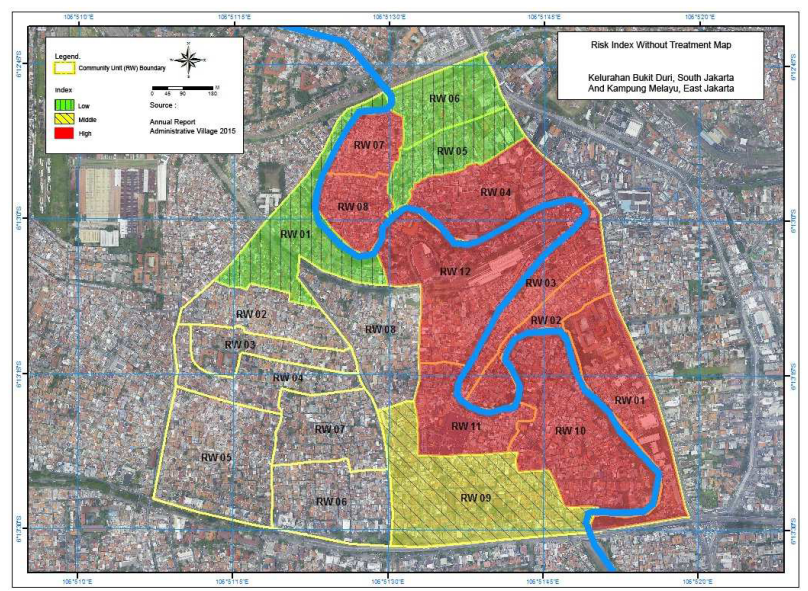

Fig. 6. Flood risk level without any action in Kampung Melayu and Bukit Duri 
The risk level of low, moderate, and high is represented in the colour of green, yellow, and red respectively. From the analysis shown in Figure 6, it can be found that from $13 \mathrm{RWs}$ in study area that has potential of being flooded, there are 9 RWs that has high risk level, which six of them were in Kampung Melayu, while the other three were in Bukit Duri. This condition were effect of the high hazard index and loss index due to the characteristics of the area which was densely covered by buildings.

\subsection{Effectiveness analysis of flood mitigations}

Considering the engineering process, action of flood control alternatives analysed in this study were those which aiming to hazard index reduction or capacity index enhancement. Those five alternatives to be analysed in this study consists of:

- floodway to East Flood Canal (KBT) with capacity design is about $90 \mathrm{~m}^{3} / \mathrm{s}$

- floodway from Pasar Minggu to West Flood Canal (KBB) with capacity design is about $260 \mathrm{~m}^{3} / \mathrm{s}$

- Ciliwung River improvement with the capacity plan of the channel is about $500 \mathrm{~m}^{3} / \mathrm{s}$

- enhancing capacity on all components by one point, and

- enhancing capacity on one component of parameters, i.e. preparedness, by two points

Floodway to KBT can reduce the inundation in Kampung Melayu and Bukit Duri by 5\% and this quite affected the hazard index in five RWs [6]. However, at the end of the analysis it can be seen in Figure 7 that this scenario can only decrease risk level in two RWs, i.e. RW 1 Kampung Melayu and RW 11 Bukit Duri. Risk level in both RWs have decreased by two levels, from high to medium, while the rest remained in the same condition.

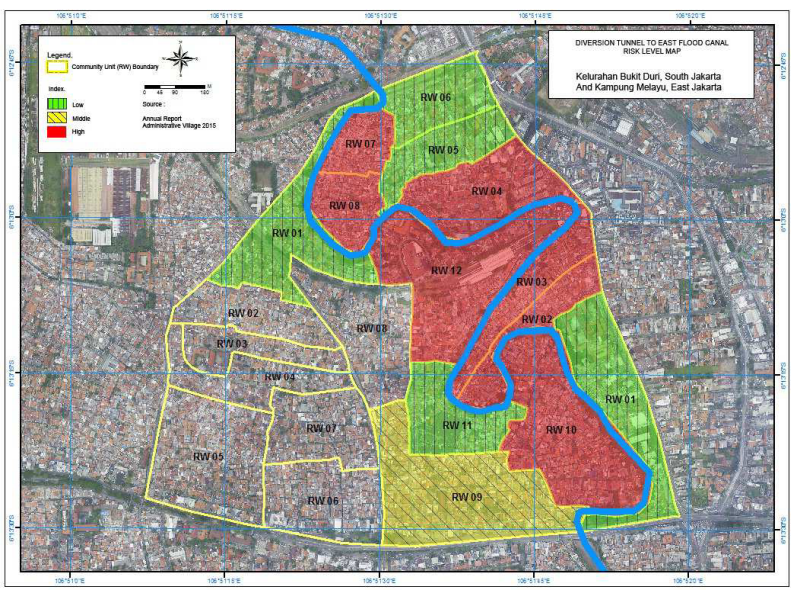

Fig. 7. Risk level in Kampung Melayu and Bukit Duri with floodway to KBT

In other hand, floodway to $\mathrm{KBB}$ can reduce inundation by $10 \%$, based on the inundation map [6], two times bigger than floodway to KBT. But apparently this is not enough to reduce the risk level better than floodway to KBT does as can be seen in Figure 8. There are only two RWs that its risk level can be reduced while the rest remained the same.

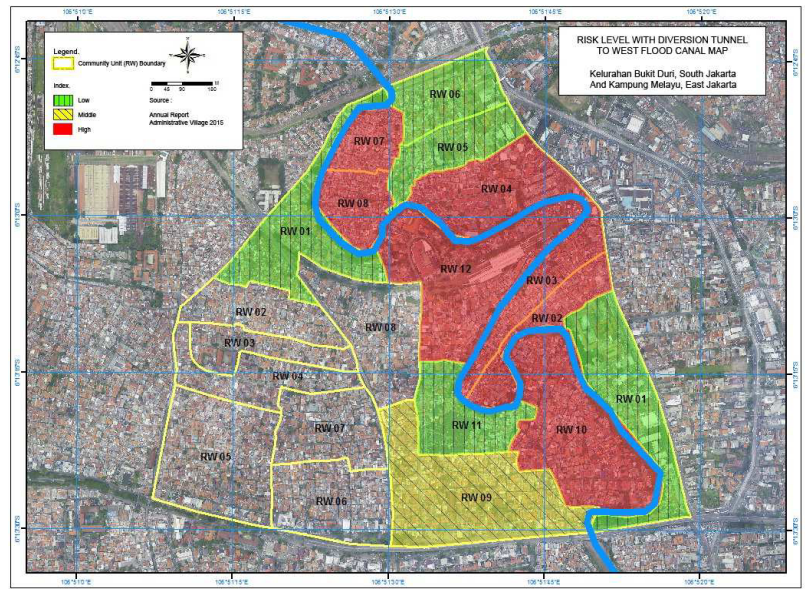

Fig. 8. Risk level in Kampung Melayu and Bukit Duri with floodway to $\mathrm{KBB}$

River improvement as the third alternative gave better result than the previous two. From inundation map [6], it is known that there are $61 \%$ inundation reduction in the study area. This scenario could reduce the hazard index significantly as in Figure 9 which affected to risk level reduction. The analysis result showed that there are four RWs which their risk level decreased from high to low, i.e. RW 1 Kampung Melayu and RW 10, 11 and 12 Bukit Duri.

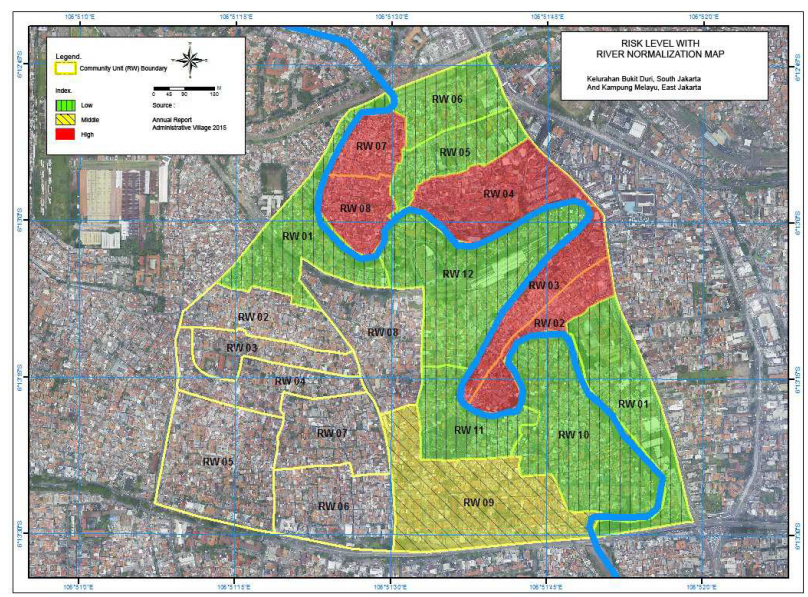

Fig. 9. Risk level in Kampung Melayu and Bukit Duri with river improvement

For capacity enhancement scenario, enhancing all capacity indicators by one point would affected the average value of capacity index. In the study area, as can be seen in Figure 10, after the enhancement of all capacity indicator, the capacity index of all RW's increased, from low to medium, or medium to high. However, it turns out that there are only two areas which the risk level can be reduced with this scenario, i.e. RW 1 Kampung Melayu and RW 9 Bukit Duri.

Last scenario alternative in this study was enhancing one component of capacity index by two points. The component that be enhanced is preparedness. With this scenario, there is a change in the capacity index of seven 
RWs located in riverside. From the analysis as in Figure 11 , it is known that there are only two RWs that the risk level could be decreased, i.e. RW 1 Kampung Melayu and RW 9 Bukit Duri. Meanwhile, there are still eight RWs with high risk level.

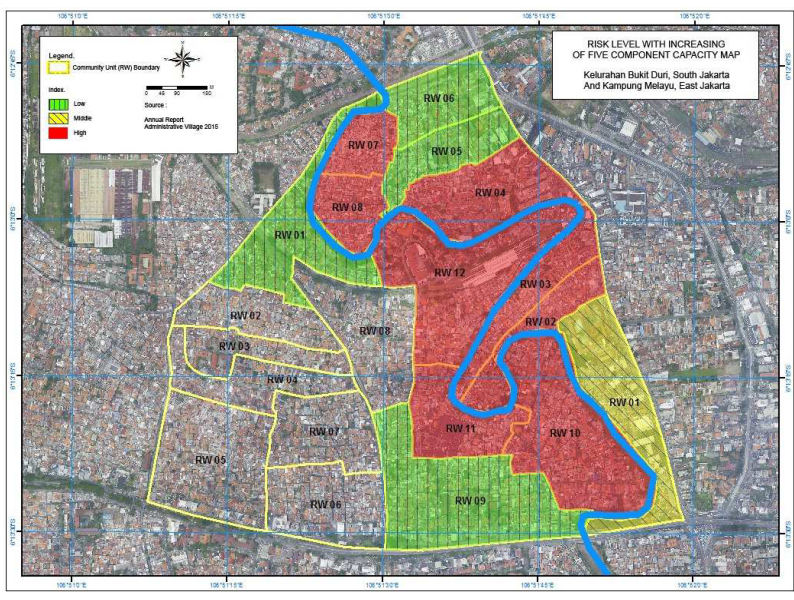

Fig. 10. Risk level in Kampung Melayu and Bukit Duri with enhancing capacity on all components by one point

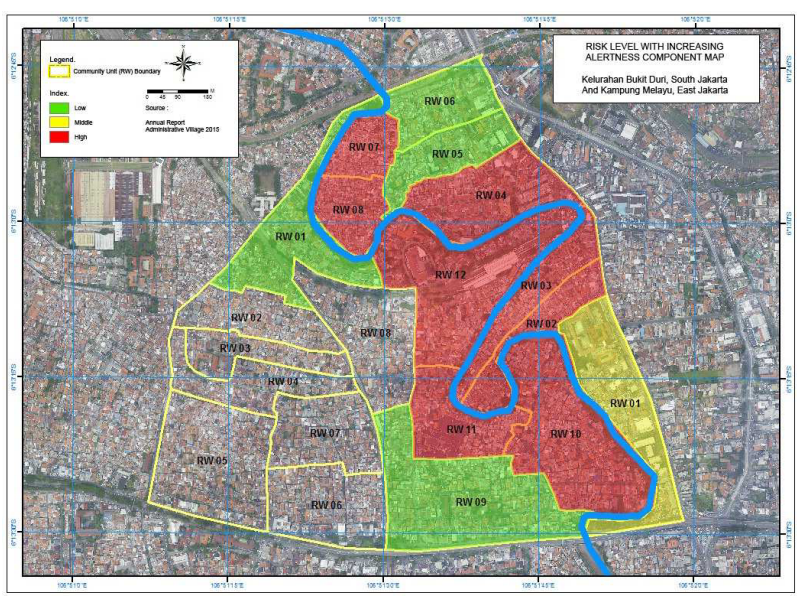

Fig. 11. Risk level in Kampung Melayu and Bukit Duri with enhancing capacity on preparedness components by two points

The effectiveness of each alternative is analyzed by comparing the investment to risk level and considering the location from the river. The investment value of floodway to KBT and river improvement are obtained from BBWS Ciliwung Cisadane River Agency (BBWS) in 2008 [13], the investment value of floodway to KBB is assumed to be proportional to investment of floodway to KBT by the channel length, while investment of capacity enhancement was referring to BPBD DKI [12], that was determined by Rp. 10 billion/level/component / year for 5 years of implementation.

The effectiveness analysis is also done by evaluating each region depends on the risk level reduction and location from the river. From these results as in Table 3, it is known that the value for flood management by river improvement could reduce the risk level of a region by $43.24 \%$, most than other scenarios. Scenario with floodway to KBT and floodway to KBB gave the same result, and it was more than result the capacity enhancement scenarios could give. These results also indicate that, in general, the effect of capacity enhancement, whether on all components or focusing on one component, was not very much different one to another. In general, those five alternative scenarios did not give a very significant impact in the study area. Five of six RWs that had high risk level remained in the same conditions due to the loss index and population exposed index in these areas were high, so that more effort was needed to reduce the risk level. One alternative for this was to combining structural and non-structural scenario in the same time.

Table 3. Summary of investment cost, risk level reduction, and investment value for each scenario of flood control in Kampung Melayu and Bukit Duri

\begin{tabular}{|c|c|c|c|}
\hline Scenario & $\begin{array}{c}\text { Investment } \\
\text { (Rp million) }\end{array}$ & $\begin{array}{c}\text { Risk } \\
\text { reduction }\end{array}$ & $\begin{array}{c}\text { Investment to } \\
\text { risk reduction } \\
\text { value } \\
\text { (Rp million) }\end{array}$ \\
\hline $\begin{array}{c}\text { Floodway to } \\
\text { KBT }\end{array}$ & $865,000.00$ & $21.62 \%$ & $4,000,625$ \\
\hline $\begin{array}{c}\text { Floodway to } \\
\text { KBB }\end{array}$ & $681,500.00$ & $21.62 \%$ & $3,151,938$ \\
\hline $\begin{array}{c}\text { River } \\
\text { improvement }\end{array}$ & $1,860,000.00$ & $43.24 \%$ & $4,301,250$ \\
\hline $\begin{array}{c}\text { All capacity } \\
\text { enhancemet }\end{array}$ & $300,000.00$ & $5.41 \%$ & $5,550,000$ \\
\hline $\begin{array}{c}\text { Preparedness } \\
\text { improvement }\end{array}$ & $120,000.00$ & $5.41 \%$ & $2,220,000$ \\
\hline
\end{tabular}

From these results, it can be concluded that even though scenario with river improvement gave the biggest effect both on inundation and risk level reduction, scenario to improve capacity on preparedness components by two levels gave the most effective results, considering its investment value.

\section{Conclusions}

Simulation using 100 years return period flood at the rate of $690 \mathrm{~m}^{3} / \mathrm{s}$ in condition without addressing any action causes $62 \%$ of the Kampung Melayu and $31 \%$ of Bukit Duri area are inundated. This causes eight RWs in Kampung Melayu and Bukit Duri had hazard index in high category, one RWs in moderate category and four RWs in the low category.

The vulnerability of the area indicated by population exposed index and loss index in most of study area are in the category of moderate and high. The capacity index in order to cope with floods in eight RWs located in the riverside are in moderate category, while the other five are in the low category. The capacity index of other seven RWs located relatively far from the river are in the low category. There were $13 \mathrm{RWs}$ in Kampung Melayu and Bukit Duri that had flood risk level. These 13 RWs were located in the riverside. From those 13 RWs, three RWs were in low level, one in moderate level and nine RWs in high level.

The impact of flood control management on inundation reduction were proportional with risk level reduction but not directly. The same results for non- 
structural scenario, which capacity index enhancement did not directly caused risk level reduction of an area. Preparedness component improvement scenario by two points were known to be the most effective of all scenarios analysis in this study due to its investment to risk level reduction, even though river improvement scenario gave the biggest impact on risk level reduction. In the case of regions with high vulnerability, in areas with high hazard index, scenario to reduce the inundation would give better effect to the risk level reduction. In the other hand, in regions with relatively low hazard index, non-structural scenario will give more significant risk level reduction than structural scenario. Flood control management by only targeting on one risk parameters would not give significant results. Because of that, for area with vulnerability that is difficult to changed, scenarios which were targeting on other two risk parameters, i.e. hazard and capacity components, were needed. For further development of this study, analysis which use vulnerability factor as function of inundation, whether depth, area, velocity, or duration, would give a more thorough result. Deeper analysis related to the weighting of each component of the capacity indicator is also needed as review for the BNPB Guideline number 2/2012 about regional capacity assessment guidance for disaster management. Furthermore, benefit analysis of a disaster management needs to take all factors that are included in investment and profits into account, such as maintenance and cycle life of the infrastructure. In areas with high vulnerability like in study area, non-structural scenario which directly connected with citizens live in the area, e.g. to increase awareness and preparedness of society needs to be an alternative for flood management, especially during structural action still has not functioned yet.

Authors would like to express their gratitude to the Ministry of Public Works and Housing Republic of Indonesia and Water Resources Engineering Research Group of Institut Teknologi Bandung for their support in this study.

\section{References}

1. M. Farid, A. Mano, K. Udo, J. Disaster Res., 7(5), 554-559 (2012)
2. Badan Perencanaan Pembangunan Nasional (Bappenas), Keterangan Menteri Negara PPN/Kepala Bappenas tentang Laporan Awal Penanganan Bencana Banjir di Wilayah Jakarta dan Sekitarnya, Bappenas, Jakarta, Indonesia (2007)

3. S. Kure, M. Farid, Y. Fukutani, A. Muhari, J.D. Bricker, K. Udo, A. Mano, J. Japan Society of Civil Engineers Series G, 70(5), 211-217 (2014)

4. M.S.B. Kusuma, H.P. Rahayu, M. Farid, M.B. Adityawan, T. Setiawati, R. Silasari, Jurnal Teknik Sipil ITB, 17(2), 123-134 (2010)

5. M. Hagemeier-Klose, K. Wagner, Nat. Hazards Earth Sys., 9, 563-574 (2009)

6. S. Ginting, Tesis Magister Pengelolaan Sumber Daya Air: Kajian dan Efektivitas Pengendalian Banjir di DKI Jakarta, Fakultas Teknik Sipil dan Lingkungan ITB, Bandung, Indonesia (2015)

7. Badan Nasional Penanggulangan Bencana (BNPB), Pedoman Umum Pengkajian Risiko Bencana, Peraturan Kepala, 2 (2012)

8. Biro Pusat Statistik (BPS) Kota Administrasi Jakarta Selatan, Statistik Daerah Kecamatan Tebet 2014, BPS, Jakarta Selatan, Indonesia (2015)

9. Biro Pusat Statistik (BPS) Kota Administrasi Jakarta Timur, Jatinegara dalam Angka 2014, BPS, Jakarta Timur, Indonesia (2015)

10. Biro Pusat Statistik (BPS) DKI Jakarta, Jakarta Dalam Angka 2014, BPS, Jakarta, Indonesia (2015)

11. A. Sarminingsih, Disertasi Doktor Teknik Sipil: Model Spasial Analisa Resiko sebagai Alternatif Penentuan Kriteria Sistem Pengendali Banjir: Studi Kasus DAS Citarum Hulu, Fakultas Teknik Sipil dan Lingkungan ITB, Bandung, Indonesia (2014)

12. Badan Penanggulangan Bencana Daerah (BPBD) DKI Jakarta, Penilaian Kerusakan dan Kerugian, serta Kebutuhan Pemulihan Pasca Banjir di Jakarta pada Januari 2013, BPBD, Jakarta, Indonesia (2013)

13. Balai Besar Wilayah Sungai (BBWS) Ciliwung Cisadane, Laporan Akhir Pekerjaan Perencanaan Teknis dan Detail Desain Penataan Sungai Ciliwung dari Pintu Air Manggarai ke Hulu, BBWS, Jakarta, Indonesia (2008)

\footnotetext{
Corresponding author: mfarid_si99@yahoo.com
} 